\title{
Assessment of stress in adolescent idiopathic scoliosis patients while wearing a brace
}

\author{
T Kuru $^{1 *}, \mathrm{H}$ Yilmaz $^{2}$ \\ From 8th International Conference on Conservative Management of Spinal Deformities and SOSORT 2011 \\ Annual Meeting \\ Barcelona, Spain. 19-21 May 2011
}

\section{Background}

The adolescent years are among the most stressful times in a person's life [1] and if they have adolescent idiopathic scoliosis (AIS), stress response can be roused by spinal deformity and increased by brace treatment. The purpose of this study is to assess stress of patients with AIS who wear a spinal brace with the "Bad Sobernheim Stress Questionnaire (BSSQ)" [2-5].

\section{Materials and methods}

Patients fulfilling that criteria were included this study 8-17 years of age, diagnosed with AIS, at least two months of experience wearing the brace. The BSSQ consists of 8 Likert-scale items. A maximum score of 24 indicates the lowest level of stress.

\section{Results}

38 patients (mean age $=13.96 \pm 3.48$; range $8-17$ ) who had came Formed Physical Therapy and Rehabilitation Clinic between March 2008 and November 2010 were included in this study and fulfilled the questionnaire. They were using Cheneau brace for $11.65 \pm 11.37$ months (range 2-30) 7 were male and 31 were female. Mean Cobb angle was $34.45^{\circ} \pm 10.89$ (range 18-57) and mean rotation angle was $6.13^{\circ} \pm 4.19$ (range $0-22$ ). The average stress value was $11.57 \pm 5.25$ (range 22-3). There was a negative correlation between brace using time and stress $(r=-0,870, p=0,03)$; and there was no correlation between age and stress $(\mathrm{r}=0,208, \mathrm{p}=0,64)$.

\section{Conclusions}

Previous studies suggested that the BSS questionnaire is reliable for deformity related stress. We used the BSSQ

${ }^{1}$ Istanbul University, Faculty of Health Sciences, Department of Physiotherapy and Rehabilitation, Istanbul, Turkey

Full list of author information is available at the end of the article and our study showed that braces in AIS treatment seem to produce stress.

\section{Author details}

${ }^{1}$ Istanbul University, Faculty of Health Sciences, Department of Physiotherapy and Rehabilitation, Istanbul, Turkey. ${ }^{2}$ Canakkale Onsekiz Mart University,

Canakkale, Turkey.

Published: 27 January 2012

\section{References}

1. Selye H: The Stress of Life. New York: McGraw-Hill; 1956.

2. Botens-Helmus C, Klein R, Stephan C: The reliability of the Bad Sobernheim Stress Questionnaire (BSSQbrace) in adolescents with scoliosis during brace treatment. Scoliosis 2006, 1:22.

3. Misterska E, Głowacki M, Harasymczuk J: Polish adaptation of Bad Sobernheim Stress Questionnaire-Brace and Bad Sobernheim Stress Questionnaire-Deformity. Scoliosis. Eur Spine J 2009, 18(12):1911-1919.

4. D'Agata, Testor CP, Rigo M: Spanish validation of Bad Sobernheim StressQuestionnaire (BSSQ (brace).es) for adolescents with braces. Scoliosis 2010, 5:15.

5. Kotwicki T, Kinel E, Stryla W, Szulc A: Estimation of the stress related to conservative scoliosis therapy: an analysis based on BSSQ questionnaires. Scoliosis 2007, 2:1.

doi:10.1186/1748-7161-7-S1-O4

Cite this article as: Kuru and Yilmaz: Assessment of stress in adolescent idiopathic scoliosis patients while wearing a brace. Scoliosis 2012 7(Suppl 1):04.

Submit your next manuscript to BioMed Central and take full advantage of:

- Convenient online submission

- Thorough peer review

- No space constraints or color figure charges

- Immediate publication on acceptance

- Inclusion in PubMed, CAS, Scopus and Google Scholar

- Research which is freely available for redistribution

\section{() Biomed Central}

